„Przekłady Literatur Słowiańskich”. T. 10, cz. 2

ISSN 2353-9763 (wersja elektroniczna)

DOI https://doi.org/10.31261/PLS.2020.10.02.06

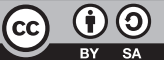

\title{
Proza macedońska XXI wieku \\ Literatura „małego narodu” w przekładach na język polski
}

\author{
21st Century Macedonian Prose \\ Literature of the "Small Nation" in Translations \\ into Polish
}

\section{Lilla Moroz-Grzelak}

iD https://orcid.org/0000-0001-5176-2804

POLISH ACADEMY OF SCIENCES

lilamor@poczta.onet.pl

Data zgłoszenia: 4.08.2019 r. ｜Ｄata akceptacji: 12.02 .2020 r.

\begin{abstract}
This article presents 21st-century Macedonian prose as it appears in contemporary Polish translation. Novels and stories by Macedonian authors are evidence of the great degreee to which this literature has recently developed. Topics under consideration include an analysis of the fine quality of modern Macedonian prose, as well as the high attainment of its Polish translators, who, using their own translation strategies, successfully transfer one cultural code to another.
\end{abstract}

KEYWORDS | Blaze Koneski, Macedonian Literature, literature of a small nation, Polish translators 
By zrozumieć fenomen literatury macedońskiej, należy przypominać, co o twórczości literackiej i przekładach na inne języki mówił Blaže Koneski (1921— 1993), uznany za kodyfikatora i głównego architekta rozwoju macedońskiej kultury i literatury ${ }^{1}$. W Testamencie poety małego narodu wskazywał on, że kwestią kluczową literatury „małego narodu”2 jest potwierdzanie jej istnienia poprzez tworzone dzieła. Macedońscy pisarze i poeci zdają się z powodzeniem wypełniać jego wolę. Koneski podkreślał też znaczenie przekładu w poznawaniu danej literatury. W cyklu rozmów prowadzonych od marca roku 1985 do kwietnia 1990 roku z pisarzem i poetą Cane Andreevskim mówił o stanie literatury macedońskiej, która w roku 1945, poza kilkoma skromnymi opowiadaniami, faktycznie nie miała swej prozy. Jednak z perspektywy lat jej powstawanie wskazywało na rosnący poziom artystyczny macedońskich utworów prozatorskich:

Земете ја само литературата, земете ја македонската проза. Четириесет и петта година воопшто ја немаше. Некои мали раскази. Скромни. А денеска ние имаме многу добри романи, што можат да стојат во секоја литература. имаме една засилена продукција. Тоа не зборува за еден процес што водел кон упадок, ами зборува за процес што водел кон издигање ${ }^{3}$.

Dla Koneskiego równie istotne było poznawanie literatur obcych tłumaczonych na język swojego narodu. Podkreślał wielką rolę w tym procesie dobrych przekładów:

А прашањето што навистина има лоши преводи, тоа е веќе друго прашање. и тука не е крив јазикот /се смее/, ами се криви лошите преведувачи и нивните работодатели. [...] И јасно ние губиме ака даваме слаби преводи. Подобро е помалку да преведуваме, а да бидат преводите, отколку на макар кого да му даваме... и нормално, ќе има и такво негодување. И јас не би читал лош превод, кога можам да читам на оригинал или на некој друг јазик подобар превод ${ }^{4}$.

Kwestia dobrego przekładu pozostaje istotna w przybliżaniu każdej literatury obcej, dlatego też w artykule wskazane zostaną prozatorskie dokonania macedońskich twórców, które w XXI wieku zostały przetłumaczone na język polski. Pozwoli to naświetlić, jak ważną rolę w ich rozpowszechnianiu odgrywa sztuka przekładu oraz pasja poznawcza jej tłumaczy, którzy jeden kod kulturowy przenoszą do drugiego. W przekładanych tekstach macedońskich autorów

1 Љ. Спасов, 2017: Блаже Конески во 21. Век. „Стожер”, nr 125, s. 5.

2 B. Koneski, 1994: Testament poety małego narodu. K. Wrocławski, tłum. „Pamiętnik Słowiański”, t. 44, s. 193-195.

3 Ц. Андреевски, 1991: Разговори со Конески. Скопје, Култура, s. 190.

4 Ibidem, s. 192. 
równie ważne jest pytanie o przyjmowane strategie translatorskie, które czynią

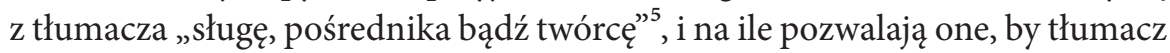
stawał się ambasadorem danej kultury. Odniosę się więc do przekładanej na język polski prozy, ze wskazaniem nazwisk jej polskich tłumaczy, podejmując próbę odpowiedzi na pytanie o ich rolę. Jak przypomina Bożena Tokarz,

przestrzeń językowa przekładu określa zakres i jakość spotkania dwóch osobowości, ponieważ język stanowi sieć, w której skupiają się procesy historyczne, społeczne, psychologiczne, etyczne, cywilizacyjne i filozoficzne, stanowiące o różnicach i podobieństwach między podmiotami zbiorowymi i jednostkowymi ${ }^{6}$.

Z kolei młoda badaczka zajmująca się przekładem, Beata Piecychna, stawiająca hipotezę „symulacji ucieleśnionej” w procesie translacji, podkreśla, że jego istotą pozostaje czytelnik, gdyż

faza czytania translacyjnego odbiega swoją specyfiką od procesów poznawczych obecnych w innych rodzajach czytania. Tłumacz bowiem musi zwracać uwagę m.in. na tzw. czytelnika docelowego - implikowanego. Musi sobie wyobrażać, jak czytelnik zrozumie tekst. Tzw. obciążenie poznawcze jest więc inne niż w procesie czytania np. dla przyjemności czy czytania ze zrozumieniem ${ }^{7}$.

Polskie przekłady literatury macedońskiej potwierdzają, że jest ona coraz lepiej rozpoznawana przez czytelników, i to nie tylko slawistów, którzy tą literaturą się zajmują ${ }^{8}$, natomiast ogromna zasługa w jej upowszechnianiu leży w kunszcie jej tłumaczy. Nie kierując się kryteriami przynależności twórców do różnych generacji pisarskich, przedstawię pokrótce opublikowane w Polsce utwory prozatorskie Luana Starovy, Goce Smilevskiego, Lidiji Dimkovskiej,

5 Kategorie te zaczerpnęłam z tytułu pracy zbiorowej M. Guławska-Gawkowska, K. Hejwowski, A. Szczęsny, red., 2012: Tłumacz: sługa, pośrednik, twórca? Warszawa, Instytut Lingwistyki Stosowanej Uniwersytetu Warszawskiego.

6 B. Tokarz, 2008: Bariery kulturowe w przekładzie. W: P. Fast, P. Janikowski, A. Olsza, red.: Odmienność kulturowa w przekładzie. Katowice, Wydawnictwo Śląsk-Częstochowa, Wydawnictwo Wyższej Szkoły Lingwistycznej, s. 7.

7 L. Tomala, 2019: Czy tłumacz symuluje w głowie to, co tlumaczy? Sprawdzi to filolożka. „PAP - Nauka w Polsce”. Dostępne w Internecie: http://naukawpolsce.pap.pl/aktual nosci/news\%2C77907\%2Cczy-tlumacz-symuluje-w-glowie-co-tlumaczy-sprawdzi -filolozka.html [dostęp: 12.08.2019].

8 Tematowi obecności literatury macedońskiej poza jej granicami poświeciłam artykuły: L. Moroz-Grzelak, 2010: Полските средби со македонската литература. W: М. Каранфиловски, И. Велев, Л. Макаријоска, ред.: Меѓународен македонистички собир. Скопје, Филолошки факултет „Блаже Конески”, s. 637-645; L. Moroz-Grzelak, 2017: Skąd się wzięła literatura macedońska? „Wyspa. Kwartalnik Literacki”, nr 4 (44), s. 4-11. 
Blaže Minevskiego, Ermisa Lafazanovskiego, Rumeny Bužarovskiej, Branka Prlji, Aleksandra Prokopieva, Žarka Kujundžinskiego oraz Radovana Pavlovskiego. W tym kontekście wspomnieć należy także o tomie Żeglarze pamięci. Antologia wspótczesnej literatury macedońskiej ${ }^{9}$, stanowiącym przegląd macedońskiej prozy, liryki i dramatu. Prezentacja literackich dokonań została w tym zbiorze poprzedzona studiami i esejami polskich oraz macedońskich badaczy literatury (Jasmina Mojsijeva Guševa, Vesna Mojsova Čepiševska, Lech Miodyński, Bogusław Zieliński), folkloru (Nina Atanasova Škrinjarik', Tanas Vražinovski, Krzysztof Wrocławski) i historii (Irena Stawowy-Kawka). Antologia stała się reprezentatywnym obrazem macedońskich osiągnięć w zakresie literatury i objęła jej najważniejszych przedstawicieli z XX i XXI wieku. Jak zaznaczyli we wstępie redaktorzy tomu, jego powstanie i edycja były możliwe tylko dzięki zaangażowaniu garstki slawistów z trzech ośrodków naukowych w kraju, podczas gdy ciężar przekładów wzięli na siebie absolwenci macedonistyki, bułgarystyki i serbistyki oraz studenci i doktoranci, których połączył entuzjazm dla Macedonii i Bałkanów ${ }^{10}$.

Na polskim rynku wydawniczym w XXI wieku ukazało się kilka ważnych utworów z literatury macedońskiej, co należy zawdzięczać determinacji tłumaczy oraz wydawców, którzy podjęli ryzyko publikacji literatury „małego narodu”. Pierwszym takim dziełem przełożonym na język polski, przyciągającym uwagę czytelników, była powieść Rozmowa ze Spinozą. Powieść-pajęczyna $(2002 / 2005)^{11}$ Goce Smilevskiego (ur. 1975) w przekładzie Hanny Karpińskiej. Książka ta odbiega od wcześniej wydawanych w Polsce utworów, które w paratekstach ${ }^{12}$ charakteryzowano jako osadzone w realiach macedońskich wierzeń, folkloru i miejscowej tradycji. Akcja powieści została umieszczona całkowicie poza czasoprzestrzenią bałkańską, a autor bohaterem uczynił Barucha Spinozę, postać historyczną z odmiennego kręgu kulturowego. Literacka biografia holenderskiego filozofa o żydowskich korzeniach stała się pretekstem do podjęcia wielkich problemów współczesności, takich jak samotność, wolność oraz potrzeba rozmowy ${ }^{13}$. Niespełna dziesięć lat później polscy czytelnicy doczekali

9 L. Miodyński, B. Zieliński, V. Mojsova Čepiševska, red., 2009: Żeglarze pamięci. Antologia współczesnej literatury macedońskiej. Poznań, Wydawnictwo Naukowe Uniwersytetu im. Adama Mickiewicza.

10 Od Redaktorów. W: L. Miodyński, B. Zieliński, V. Mojsova Čepiševska, red., 2009: Żeglarze pamięci..., s. 9-10.

11 W nawiasach podaję rok pierwszego wydania utworu w Macedonii i polskiego przekładu.

12 M. Gawlak, 2017: Wstęp. „Przekłady Literatur Słowiańskich”, t. 8, cz. 1: Parateksty w odbiorze przekładu, s. 7-11.

13 Utwór wzbudził ogromne zainteresowanie krytyków i czytelników. Por. teksty: A. Kaczorowskiego („Gazeta Wyborcza” 2005, nr 237); D. Skrabka („Arte” 2005, nr 4); 
się przekładu kolejnego utworu Smilevskiego - powieści Siostra Zygmunta Freuda (2010/2014). Dzieło to - przełożone na ponad 30 języków - w chwili ukazania się polskiej wersji w udanym przekładzie Natalii Łukomskiej było już uhonorowane Europejską Nagrodą Literacką za rok 2010 oraz Nagrodą Kultury Śródziemnomorskiej za rok 2012. Sam utwór zdaje się mistrzowskim dążeniem do twórczej doskonałości autora, gdyż jego pierwsze macedońskie wydanie pod tym samym tytułem z roku 2007 liczyło zaledwie 181 stron, drugie, poprawione przez pisarza, które stało się podstawą przekładów na inne języki, było dziełem już znacznie dłuższym, liczącym 313 stron $^{14}$. Przenosząc na pierwszy plan postać jednej z czterech sióstr Freuda - Adolfiny - pisarz ukazał świat jej przeżyć w zmieniających się okolicznościach — od jej losów $\mathrm{w}$ przepełnionym artystyczną atmosferą Wiedniu z początku XX wieku po doświadczenia w obozie koncentracyjnym w Terezinie. Książka, przedstawiając koleje życia sióstr Freuda w ich dążeniu do szczęścia, stała się powieścią o poszukiwaniu miejsca człowieka w życiu i w pamięci potomnych. Oba wzmiankowane utwory - podobnie jak kolejna, nietłumaczona powieść Bpaḱarbemo на зборовите (2015), ukazująca dzieje miłości Heloizy i Abelarda — osadzone zostały poza macedońską czasoprzestrzenią. Stały się przykładem sztuki pisarskiej, w której, wykorzystując materiały źródłowe, autor stworzył własne wizje literackie związane z postaciami historycznymi i odniósł je do problemów współczesności. Jego podejście do materii pisarskiej sprawiło, że w swoim kraju Smilevski został uznany anachronicznie przez jednego z krytyków za twórcę „powieści archeologicznej”"15.

Tematycznym powrotem do macedońskiej przestrzeni jest powstała jeszcze w XX wieku powieść Czasy kóz (1993/2005) z cyklu prozatorskiego Bałkańska saga. Jej autora - Luana Starovy (ur. 1941) - w polskiej wersji Wikipedii przedstawiono jako „pisarza albańskiego mieszkającego i tworzącego

J. Maksymiuk-Lipszyc („Lampa” 2006, nr 1); B. Pieńkowskiej („Nowe Książki” 2006, nr 4); L. Moroz-Grzelak (Piękno, którego zabrakło. Rozmowa z pisarzem Goce Smilevskim. „Rzeczpospolita” 2006, nr 54).

14 Dla pisarza są to dwa różne utwory. Wydanie rozszerzone powieści z pierwszą łączy przede wszystkim postać głównej bohaterki. Autor zrezygnował w nim z kronikarskich odniesień do dat i literackiego kreślenia noty biograficznej Zygmunta Freuda, usuwając wszelkie informacje z pierwotnego wariantu mówiące o tym, kiedy ten skończył studia, rozpoczynał praktykę lekarską, kiedy zrezygnował z pracy w klinice, kiedy zaczęły się pojawiać jego pierwsze problemy ze zdrowiem w związku z nałogiem palenia papierosów. Smilevski mówi o tym w rozmowie, jaką przeprowadziłam z pisarzem w 2015 roku. Por. L. Moroz-Grzelak, 2015: Freud i Macedonia: Rozmowa z Goce Smilevskim. Dostępne w Internecie: http://balkanistyka.org/freud-i-macedonia-rozmowa -z-goce-smilevskim/ [dostęp: 8.07.2019].

15 Р. Алаѓозовски, 2016: За отсутното. „Економија и бизнис”, nr 221. 
w Macedonii Północnej”16. Utwór, nominowany do Nagrody Jeana Moneta dla Najlepszej Powieści Europejskiej, w Polsce znalazł się w gronie finalistów Literackiej Nagrody Europy Środkowej Angelus. Akcja powieści rozgrywa się $\mathrm{w}$ realiach nowej macedońskiej republiki w systemie federacyjnej Jugosławii, gdzie w myśl wprowadzanych przez władzę zasad podjęto decyzję o likwidacji z miejscowego krajobrazu kóz - zwierząt, które w trudnych czasach broniły przed głodem i pozwalały przetrwać ludności. Kolejna odsłona macedońskiej literatury, ukazująca bałkańską specyfikę epoki komunizmu stała się przedmiotem wielu omówień w polskiej prasie ${ }^{17}$, a na jej sukces wpłynął także kunszt tłumaczki - Doroty Jovanki Ćirlić.

Polskich przekładów swych utworów doczekała się również poetka ${ }^{18}$ i pisarka Lidija Dimkovska (ur. 1971). Jej pierwsza powieść, Ukryta kamera $(2006 / 2010)^{19}$, po czterech latach od wydania oryginału ukazała się w tłumaczeniu Danuty Cirlić-Straszyńskiej. Utwór, określany przez krytyków jako powieść o nomadyzmie, stanowi swego rodzaju dziennik pisany przez bohaterkę, której życiorys przypomina losy samej autorki. Narratorką uczyniono tytułową ukrytą kamerę - mikroskopijny chip znajdujący się w palcu nogi bohaterki. Chociaż akcja utworu koncentruje się na okresie jej trzymiesięcznego pobytu na stypendium artystycznym w Wiedniu, to pisarka przenosi czytelnika do okresu dzieciństwa bohaterki spędzonego w Macedonii i wczesnej młodości, a także studiów w Rumunii i pracy w Bukareszcie oraz wyjazdów literackich do USA, Tajwanu czy Szwecji. Inne ${ }^{20}$ z dzieł Dimkovskiej, Non-Oui (2016/2019), również ukazało się w świetnym przekładzie Danuty Cirlić-Straszyńskiej. Powieść, którą z Macedonią może łączyć jedynie wspólnota losów republiki wchodzącej w skład federacji jugosłowiańskiej, przenosi czytelnika do chorwackiego Splitu

16 Zob. Luan Starova. Dostępne w Internecie: https://pl.wikipedia.org/wiki/Luan_Starova [dostęp: 8.07.2019].

17 L. Starova, 2005: Czas kóz. D.J. Ćirlić, tłum. Warszawa, Oficyna 21. Zob. teksty P. Wilka („Rzeczpospolita” 2005, nr 57); E. Cichowicz („Nowe Książki” 2005, nr 8); M. Radgowskiego („Rzeczpospolita” 2006, nr 258).

18 L. Dimkovska jest też autorką wydanego w Polsce i nominowanego do nagrody Europejski Poeta Wolności 2016 tomiku poezji pH neutralna wobec życia i śmierci (Gdańsk, Słowo/Obraz Terytoria, 2015) oraz wierszy, które obok twórczości Jovicy Taševskiego-Eternijana i Vladimira Ilevskiego znalazły się w kwartalniku literackim „Wyspa” 2017, nr 4.

19 Krótkie fragmenty powieści ukazały się wcześniej w przekładzie Mirelli Makurat w antologii Żeglarze pamięci..., s. 245-250.

20 Polski rynek wydawniczy bardzo ostrożnie podszedł do drugiej powieści L. Dimkovskiej Резервен живот (2012), której fragmenty przetłumaczyła Danuta Cirlić-Straszyńska. Być może dla potencjalnych wydawców tego dzieła niewiarygodnym konceptem wydawała się opowieść o perypetiach w federacyjnej Jugosławii zrośniętych głowami sióstr syjamskich. 
z okresu poprzedzającego II wojnę światową i samej wojny, a także do titowskiej Jugosławii oraz na mafijną Sycylię. W założeniu autorki przedstawione na tle historycznym losy bohaterki pozwalają dotrzeć do głębi uczuć człowieka, kryjącego w swym wnętrzu o wiele bardziej złożone warstwy niż te, widoczne na powierzchni, kiedy na stawiane pytania możliwa jest tylko jedna $\mathrm{z}$ dwóch odpowiedzi: nie lub tak ${ }^{21}$.

Innym prozaikiem, którego utwór przełożono na język polski, jest Blaže Minevski (ur. 1961). Jego powieść Celownik (2007/2018) w tłumaczeniu Elżbiety Ćirlić w Polsce znalazła się na długiej liście 105 utworów zgłoszonych do Literackiej Nagrody Europy Środkowej Angelus za 2019 rok, a następnie wśród 14 nominowanych półfinalistów ${ }^{22}$. Pisarz, ukazując losy głównego bohatera, zastosował sztukę opowiadania o charakterze skazu, z typową dla gatunku narracją w pierwszej osobie i z licznymi powtórzeniami. Sekwencje barwnych, brawurowo opowiedzianych historii z różnych etapów życia bohatera, przedstawione w kolorycie czasów minionych, spojone narracyjną teraźniejszością konfliktu etnicznego, odnoszą się nie tylko do zmienności ludzkich losów, lecz także do kwestii rynku czytelniczego „małego narodu”, do sztuki pisania i pozycji twórcy czy wreszcie do odbioru dzieł literackich w Macedonii. Autor odsłania specyfikę rynku wydawniczego i rolę krytyki literackiej w sytuacji, kiedy zapomina się, że dla istnienia dzieła najważniejszy jest czytelnik.

Powieścią Hrapeszko w polskim przekładzie (2006/2015) zaistniał także prozaik Ermis Lafazanovski (ur. 1961). Tłumaczenie utworu dokonane przez Anetę Sapetę zaanonsowało pisarstwo tego autora, ukazując kreację bohatera rozdartego pomiędzy tym, co własne, a tym, co poznane i ciągle poznawane w nowym kręgu kulturowym. Ta właśnie powieść stała się okazją do podjęcia dyskursu na temat miejsca bałkańskiej i słowiańskiej Europy w dziedzictwie kulturowym kontynentu. Tytułowy bohater, Macedończyk, w trakcie swych peregrynacji po Europie odkrył w sobie — poza umiejętnością mistrzowskiego przycinania winorośli - talent do tworzenia niezwykłych szklanych przedmiotów. Już jako uznany artysta rozpoczął życie w rozdarciu pomiędzy sztuką a zwykłym rzemiosłem, między dwoma światami - mitycznym dla niego Zachodem a nieodkrytym, nieznanym i dzikim dla przedstawicieli tego świata

21 L. Moroz-Grzelak, 2019: Literackie inspiracje. Rozmowa z Lidiją Dimkovska, autorka powieści „Non-Oui”. „Książki. Magazyn Literacki”, nr 4, s. 20-21.

22 Oto ksiażki nominowane do Literackiej Nagrody Europy Środkowej Angelus w 2019 roku. Dostępne w Internecie: https://wroclaw.naszemiasto.pl/oto-ksiazki-nominowane-do -literackiej-nagrody-europy/ar/c13-5200361 [dostęp: 25.08.2019]. Nagrodę otrzymał pisarz bułgarski Georgi Gospodinow za powieść Fizyka smutku. Dostępne w Internecie: https://angelus.com.pl/2019/10/georgi-gospodinow-laureatem-literackiej-na grody-europy-srodkowej-angelus-2019/ [dostęp: 12.02.2020]. 
Wschodem. Jak stwierdził sam pisarz, jego celem było ukazanie aktualnego zderzenia cywilizacji. W tej właśnie powieści świat realny skonfrontowany jest z wyobrażonym, otwierając pole do interpretacji i szukania odpowiedzi na pytanie, na ile opisywany świat istnieje i czy mógłby istnieć faktycznie ${ }^{23}$.

W gronie autorów, których dzieła tłumaczone są na język polski, znalazł się również prozaik i dramaturg Žarko Kujundžiski (ur. 1980). Jego debiutancką powieść Spectator (2003/2012) przetłumaczyły Zofia Dembowska i Gabriela Łukowska.

Utwory macedońskich pisarzy, często obok prozy uprawiających również poezję, publikowane są nie tylko w zwartych tomach książkowych, lecz także we fragmentach na łamach pism literackich. W ten sposób przedstawiono polskiemu czytelnikowi inną powieść Lafazanovskiego - Historia ludzi, którzy umarli ze strachu (2012/2018), jej fragmenty w przekładzie Hanny Karpińskiej ukazały się na łamach czasopisma „Fraza”. Dając dobry przykład sztuki opowiadania, autor przedstawił literacki obraz środowiska kilkunastu cudzoziemców, emigrantów i uciekinierów politycznych, którzy w latach 70 . XX wieku czasowo zamieszkali w przydzielonym im baraku na peryferiach Skopje. Lafazanovski wykreował interesujące postacie, a budując obraz realny, który z zewnętrznej perspektywy postrzegania mógłby wydawać się niewiarygodny, ujął smutki i radości codzienności. Dla macedońskich krytyków ten właśnie utwór stał się przykładem powieści o antropologii strachu i strategiach manipulacyjnych, które wykorzystują strach jako codzienną broń dla przytępienia zmysłów ${ }^{24}$.

Poznawanie literatury macedońskiej umożliwiają też krótkie formy prozatorskie, które ukazały się w zbiorkach wydawanych przez miłośników literatury słowiańskiego południa Europy. Wśród nich znalazły się opowiadania Aleksandra Prokopieva (ur. 1953) Mały człowiek: bajki z lewej kieszeni (2011/2012) w przekładzie Anety Todevskiej i Michała Sapety. Każda z szesnastu ironicznych, pozbawionych bajkowego kolorytu historii - bajek, kierowanych do dorosłych, odnosi się do miłości, przyjaźni, zdrady, braku zrozumienia, wierności czy samotności. Inny sposób narracji zastosowano w następnym wydanym zbiorze opowiadań urodzonego w Sarajewie, a mieszkającego od roku 1990 w Skopje, Branka Prlji (ur. 1977), Jak trzymać parasol bez ręki (2013/2015), w przekładzie Zofii Dembowskiej. Krótkie historie opowiedziane z wykorzystaniem gry słów zderzają w sobie absurdalność otaczającego świata z odczuwaniem piękna rzeczy małych, którego nie zauważa się w pędzie współczesnego życia.

23 Temat ujęłam we wcześniejszym artykule, por. L. Moroz-Grzelak, 2012: Bałkańskie kompleksy "gorszej Europy” w prozie Ermisa Lafazanovskiego. „Slavia Meridionalis”, t. 12 , s. $45-56$.

24 Историјата на луѓето кои умреа од страв. Dostępne w Internecie: https://kupik niga.mk/product/istorijata-na-lugeto-koi-umrea-od-strav/ [dostęp: 10.08.2018]. 
Inna droga przybliżenia polskiemu czytelnikowi krótkich form literatury macedońskiej wiąże się z promocją literatur europejskich $\mathrm{w}$ ramach projektu „Nowe głosy z Europy” zainicjowanego przez Biuro Literackie. Na stronie internetowej wydawnictwa w piśmie „Biblioteka. Magazyn Literacki” zaprezentowano fragment opowiadania Lilka (2016) ${ }^{25}$ Rumeny Bužarovskiej (ur. 1981) w tłumaczeniu Aleksandry Kamińskiej. Przekład kolejnego opowiadania tej autorki, Ojciec (2018), opublikowano na łamach kwartalnika literackiego „Inter-. Literatura-Krytyka-Kultura” w tłumaczeniu Eleny Micevskiej-Zmejkoskiej i Arkadiusza Granosa. Utwory Bužarovskiej wpisują się w nurt prozy psychologicznej, w której kobiety, bohaterki ukazywane w otoczce społeczno-politycznej rzeczywistości Macedonii, przeżywają swoje dramaty. Ich losy przedstawiane z lokalnej, macedońskiej perspektywy odzwierciedlają uniwersalne problemy człowieka w każdym innym miejscu na świecie.

Od wskazanych tekstów odbiega gatunkowo przetłumaczony i opublikowany na łamach kwartalnika „Wyspa. Kwartalnik Literacki” esej poety i prozaika Radovana Pavlovskiego (ur. 1937) - Lizbońskie noce (1992/2019). Pierwotnie ukazał się on w dzienniku „Nova Makedonija”, a po latach, w 2018 roku, wraz z innymi tekstami autora, poświęconymi między innymi dziedzictwu Aleksandra Wielkiego, został opublikowany w zbiorze esejów. Utwory w nim zawarte macedoński badacz i krytyk literatury Gane Todorovski zaklasyfikował do grupy esejów politycznych, które wpisują się do skarbca kultury narodowej macedońskiej aforystyki ${ }^{26}$. Napisany z użyciem epitetów, metafor i porównań tekst Pavlovskiego, odnosząc się do pierwszych rozmów, jakie prowadzono na szczycie państw Unii Europejskiej w Lizbonie, gdy debatowano nad ogłoszoną w 1991 roku suwerennością Macedonii, nie stracił swej aktualności, potwierdzając tezę, że o losach tego małego kraju nadal decydują inni ${ }^{27}$.

Dzieła wspomnianych tu dziesięciorga pisarzy dokumentują rozwój i stan literatury macedońskiej końca XX wieku i pierwszych dwóch dekad nowego stulecia, świadczą o jej poziomie. Wcześniej, nim wydano ich polskie przekłady, niemal wszystkie zostały docenione w Macedonii, zdobywając czy to tytuł powieści roku pisma „Utrinski vesnik” (m.in.: 2002 - G. Smilevski; 2007 - B. Minevski), czy to nagrodę Stowarzyszenia Pisarzy Macedońskich Stale Popov (np. 2005 i 2013 - L. Dimkovska). Niektóre z prozatorskich dokonań nominowane były

25 R. Bužarovska, [online]: Lilka. [Premierowy fragment opowiadania]. A. Kamińska, tłum. Dostępne w Internecie: https://www.biuroliterackie.pl/biblioteka/utwory/ lilka/ [dostęp: 12.08.2019].

26 Г. Тодоровски, 2018: Афирмација на политичкиот есеј. W: Р. Павловски, Александар и иунглата. Скопје, Матица македонска, s. 274.

27 R. Pavlovski, 2019: Lizbońskie noce. L. Moroz-Grzelak, tłum. „Wyspa. Kwartalnik Literacki", nr 4 (52), s. 26-28. 
do nagrody regionalnej Balkanika, zyskując uznanie międzynarodowego jury

146 (2010 - A. Prokopiev; 2018 - L. Dimkovska). Żadne z przetłumaczonych dzieł nie pozostało bez reakcji krytyków i czytelników. W sposób autoironiczny do kwestii rynku czytelniczego odniósł się Blaže Minevski. Bohater i narrator jego powieści Celownik mówi:

Została [powieść - L.M.G.] bardzo dobrze przyjęta przez czytelników i krytykę, co było wręcz nieprawdopodobne w naszych warunkach. Wszyscy podzielali opinię, że chodzi tu o światową powieść, która powstała w małym języku: o szokujące dzieło z nieangielskiego obszaru językowego, o powieść która z pewnością zostanie światowym bestsellerem. [...] Ponadto kilku wybitnych krytyków publicznie twierdziło, że Celownik: jest pierwszą naszą powieścią, którą bez problemu można przetłumaczyć na wszystkie duże języki, i która bezpośrednio, bez żadnych protekcji, lobbingu i pieniędzy państwowych, sama wejdzie na wszystkie światowe listy bestsellerów, zaistnieje, przebije się. Kilku nawet napisało, że mamy do czynienia $\mathrm{z}$ arcydziełem literatury światowej, czy wręcz $\mathrm{z}$ pisarzem, który wstrząśnie światem ${ }^{28}$.

Za docenieniem przez krytyków w wymiarze krajowym i regionalnym szło zwykle zainteresowanie czytelnicze, które także obnaża Minevski we wzmiankowanym tu utworze, ujawniając przy tym kulisy oddziaływania na potencjalnego odbiorcę przez mnożenie pojawiających się w Macedonii kolejnych edycji:

[...] co dwa tygodnie ukazywało się nowe wydanie, co miało znaczyć, że poprzednie zostało już wyprzedane. Przy czym opinia publiczna nie miała pojęcia, że nowe wydania drukują się w dziesięciu egzemplarzach, i że z tych dziesięciu egzemplarzy czasami robi się dwa wydania ze zmienioną okładką ${ }^{29}$.

Bez względu jednak na manipulacje dokonywane na rynku wydawniczym wskazany w powieści efekt docenienia przez krytyków i czytelników przekłada się zwykle na zainteresowanie poza granicami, nawet gdy utwór jest przetłumaczony na trzy języki sąsiednich krajów, wprawdzie też „małe”, ale za to ważne dla poszerzania rynku czytelniczego powieści ${ }^{30}$.

W kontekście nagradzania twórczości macedońskich autorów niezwykle istotny jest fakt, że to tłumacze śledzą nowości rynku wydawniczego, a kierując się własnym poczuciem estetyki, decydują się na przekład danego utwo$\mathrm{ru}$, przynależnego do niszowej $-\mathrm{z}$ punktu widzenia literatur o wielkich tradycjach - literatury macedońskiej. Ową niszowość problematyki mace-

28 B. Minevski, 2018: Celownik. E. Ćirlić, tłum. Warszawa, Biblioteka Słów, s. 281.

29 Ibidem, s. 282.

30 Ibidem. 
dońskiej w ogóle zdaje się potwierdzać Lidija Dimkovska w powieści Ukryta kamera. $\mathrm{W}$ jednym $\mathrm{z}$ jej fragmentów wskazała na protekcjonalizm świata zachodniego w podejściu do przedstawicieli „małych narodów”, a także do ich literatury - według austriackiego ankietera reprezentującego fundatora stypendium „małe narody” najlepiej byłoby utrzymywać w stanie zapóźnienia i stagnacji ${ }^{31}$.

Na sukces literatury macedońskiej w Polsce wpływa nie tylko wybór jej najlepszych tekstów. Równie ważny pozostaje dobry przekład, za pośrednictwem którego dzieło ma trafić do czytelnika z innego kręgu kulturowego. Zdają sobie z tego sprawę tłumacze podejmujący się przekładów i zwracający uwagę na problemy translacyjne w procesie tworzenia polskiego ekwiwalentu tłumaczonego tekstu. Dla Natalii Łukomskiej ewentualne rozbieżności pomiędzy przekładem a tekstem oryginalnym wynikają ze struktury języka i braku odpowiednich form gramatycznych. Częściowo są też „rezultatem świadomych wyborów tłumacza stawiającego wyżej wierność semantyczną niż analogię formalną - wynikają zatem ze strategii translatorskich"32. Dla macedonisty i językoznawcy Macieja Kawki istotą przekładu pozostaje

ekwiwalencja, jako technika tłumaczeniowa, dzięki której oddaje się sens wyrażenia języka wyjściowego przez odpowiadające mu w języku docelowym inne wyrażenie, mające inną formę, ale wyrażające ten sam sens lub idee i dotyczy zwłaszcza tłumaczenia wyrażeń skostniałych, frazeologizmów, przysłów lub powiedzen $^{33}$.

Poznawanie literatury macedońskiej w Polsce nie byłoby możliwe także bez determinacji wydawców, którzy podjęli ryzyko jej publikacji. Zmiany, jakie dokonały się pod koniec XX wieku, przetasowały polski rynek książki. Przestała istnieć nawiązująca do przedwojennej tradycji wydawniczej Julije Benešicia, zainicjowana przez Wydawnictwo Łódzkie seria Biblioteka Jugosłowiańska (1970-1995), w ramach której publikowano dokonania literackie narodów Jugosławii. Obecnie nowe wydawnictwa, najcześciej prywatne, nastawione są przede wszystkim na kontakt $\mathrm{z}$ dobrą literaturą. Taki cel przyświeca wydawnictwu Oficyna 21, którego „priorytetem jest promowanie literatury wysokoartystycznej i wspieranie najwartościowszych poszukiwań badawczych

31 L. Dimkovska, 2010: Ukryta kamera [Скриена камера]. D. Cirlić-Straszyńska, tłum. Warszawa, PIW, s. 31.

32 N. Łukomska, 2011: Polskie ekwiwalenty macedońskiej formy „glagolski prilog” w polskim przekładzie „Rozmowy ze Spinoza” Goce Smilevskiego. „Folia Philologica Macedono-Polonica", t. 8, s. 447.

33 M. Kawka, 2011: Między ekwiwalencją dynamiczną a formalna w polskim przekładzie „Wielkiej wody” Żiwka Czinga. „Folia Philologica Macedono-Polonica”, t. 8, s. 423. 
z zakresu humanistyki" ${ }^{34}$, czy powstałemu całkiem niedawno wydawnictwu Biblioteka Słów, które stawia sobie za cel promocję „różnych odcieni literatury — rodzimej i zagranicznej, ze szczególnym naciskiem na literaturę bałkańską i »małych języków «" ${ }^{35}$. Również Wydawnictwo W.A.B. postawiło przed sobą ambitne zadanie propagowania dobrej literatury ${ }^{36}$. Takie były też motywy działania pozawarszawskiego wydawnictwa Toczka, założonego przez fascynatów literatury słowiańskiego południa, którzy połączyli swą sympatię do Bałkanów z pasją propagowania dobrej prozy.

Jednak, jak się wydaje, na popularyzacji literatury „małego narodu” ciąży zauważalna nadal w Polsce stygmatyzacja przestrzeni bałkańskiej. Zdaje się to potwierdzać wypowiedź niestrudzonej tłumaczki literatur południowosłowiańskich Danuty Cirlić-Straszyńskiej, której polski czytelnik zawdzięcza też wcześniejszy kontakt z prozą macedońską, gdy po raz pierwszy miał okazję dotrzeć do polskiego przekładu twórczości pisarza i dramaturga Živka Činga (1935-1987). W rozmowie zamieszczonej w zbiorze wywiadów ze znaczącymi postaciami polskiego życia społecznego i kulturalnego tłumaczka opowiedziała o swej przygodzie z pewnym wydawnictwem. Otóż zaoferowała przekład jednego z najlepszych dokonań literackich słowiańskiego południa Europy, a po próbach kontaktu z redaktorem tegoż wydawnictwa usłyszła w odpowiedzi, że choć proponowany tekst się podoba, to jednak nie zostanie wydrukowany. W odpowiedzi na postawione pytanie: „Dlaczego?”, usłyszała: „[...] bo to są Bałkany, to by źle podziałało na naszą sprzedawalność"37. Sama wypowiedź, niezależnie od wartości ocenianej literatury, potwierdza jedynie zakorzenienie stereotypów ciążących na tym regionie.

Literatura macedońska pozostaje nadal literaturą „małego narodu”. Powstawanie jej polskich przekładów zależy nie tylko od kunsztu i pasji tłumaczy, lecz także od ich determinacji w poszukiwaniu wydawców, którzy stawiają sobie za cel promocję dobrej literatury. Polscy tłumacze literatury macedońskiej stają się tym samym jej ambasadorami i jednocześnie jej twórcami. W ten sposób, podobnie jak poeci i prozaicy macedońscy, z powodzeniem realizują testament Koneskiego, ukazując polskim odbiorcom rozwój literatury macedońskiej i prezentując jej najlepsze dokonania.

34 Kultura. Możliwość. Działanie, [online]. Dostępne w Internecie: http://www.oficyna21. $\mathrm{pl} /$ index.php [dostęp: 4.07.2019].

35 Łączymy różne odcienie literatury, [online]. Dostępne w Internecie: http://biblioteka -slow.pl/o-nas/ [dostęp: 8.07.2019].

36 Zob. stronę internetową Wydawnictwa W.A.B.: https://www.facebook.com/wydawnic two.wab [dostęp: 8.07.2019].

37 J. Dąbrowska, 2019: Miłość jest warta starania. Rozmowy z mistrzami. Warszawa, Agora, s. 220. 


\section{Literatura podmiotu}

Bužarovska R., 2016: Lilka [Лилка]. A. Kamińska, tłum. „Biblioteka. Magazyn

Literacki”. Dostępne w Internecie: https://www.biuroliterackie.pl/biblioteka/ utwory/lilka/ [dostęp: 23.07.2019].

Bužarovska R., 2018: Ojciec [Tamкo]. E. Micevska Zmejkoska, A. Granos, tłum. „Inter-. Literatura-Krytyka-Kultura”, nr 4 (18). Dostępne w Internecie: https:// pismointer.wordpress.com/aktualny-numer/przeklady/rumena-buzarowska -ojciec/ [dostęp: 22.07.2019].

Dimkovska L., 2010: Ukryta kamera [Скриена камера]. D. Cirlić-Straszyńska, tłum. Warszawa, PIW.

Dimkovska L., 2019: Non-Oui [Нон - Yu]. D. Cirlić-Straszyńska, tłum. Warszawa, Biblioteka Słów.

Kujundžiski Ž., 2012: Spectator [Spectator]. Z. Dembowska, G. Łukowska, tłum. Katowice, Wydawnictwo Uniwersytetu Śląskiego.

Lafazanovski E., 2015: Hrapeszko [Храпершко]. A. Sapeta, tłum. Radziechowy, Wydawnictwo Toczka.

Lafazanovski E., 2018: Historia ludzi, którzy umarli ze strachu [Иcmoрија на леѓето кои умреа од страв]. H. Karpińska, tłum. „Fraza. Poezja. Proza. Esej", nr 2 (100), s. 26-48.

Minevski B., 2018: Celownik [Нишан]. E. Ćirlić, tłum. Warszawa, Biblioteka Słów.

Pavlovski R., 2019: Lizbońskie nосе [Лисабонски ноќи]. L. Moroz-Grzelak, tłum. „Wyspa. Kwartalnik Literacki”, nr 4 (52), s. 26-28.

Prlja B., 2015: Jak trzymać parasol bez ręki [Чадор без рака да го држи]. Z. Dembowska, tłum. Radziechowy, Wydawnictwo Toczka.

Prokopiev A., 2012: Mały człowiek: bajki z lewej kieszeni [Човечулец: бајки од левиот иеб]. A. Todevska, M. Sapeta, tłum. Radziechowy, Wydawnictwo Toczka.

Smilevski G., 2005: Rozmowa ze Spinoza. Powieść - pajęczyna [Разговор со Спиноза: роман - пајажина]. H. Karpińska, tłum. Warszawa, Oficyna 21. Smilevski G., 2014: Siostra Zygmunta Freuda [Сестрата на Зигмунд Фројд]. N. Łukomska, tłum. Warszawa, Wydawnictwo W.A.B.

Starova L., 2005: Czasy kóz [Времето на козите]. D.J. Ćirlić, tłum. Warszawa, Oficyna 21.

Miodyński L., Zieliński B., Mojsova Čepiševska V., red., 2009: Żeglarze pamięci. Antologia współczesnej literatury macedońskiej. Poznań, Wydawnictwo Naukowe Uniwersytetu im. Adama Mickiewicza. 


\section{Literatura przedmiotu}

Dąbrowska J., 2019: Miłość jest warta starania. Rozmowy z mistrzami. Warszawa, Wydawnictwo Agora.

Gawlak M., 2017: Wstęp. „Przekłady Literatur Słowiańskich”, t. 8, cz. 1: Parateksty w odbiorze przekładu, s. 7-11.

Kawka M., 2011: Między ekwiwalencją dynamiczna a formalna w polskim przekładzie „Wielkiej wody” Żiwka Czinga. „Folia Philologica Macedono-Polonica”, t. 8, s. $423-438$.

Koneski B., 1994: Testament poety małego narodu. K. Wrocławski, tłum. „Pamiętnik Słowiański”, t. 44, s. 193-195.

Łączymy różne odcienie literatury, [online]. Dostępne w Internecie: http://biblio teka-slow.pl/o-nas/ [dostęp: 8.07.2019].

Łukomska N., 2011: Polskie ekwiwalenty macedońskiej formy "glagolski prilog” w polskim przekładzie „Rozmowy ze Spinoza” Goce Smilevskiego. „Folia Philologica Macedono-Polonica”, t. 8, s. 447-453.

Moroz-Grzelak L., 2012: Bałkańskie kompleksy „gorszej Europy” w prozie Ermisa Lafazanovskiego. „Slavia Meridionalis”, t. 12, s. 45-56.

Moroz-Grzelak L., 2015: Freud i Macedonia: Rozmowa $z$ Goce Smilevskim. Dostępne w Internecie: http://balkanistyka.org/freud-i-macedonia-rozmowa-z -goce-smilevskim/ [dostęp: 8.07.2019].

Moroz-Grzelak L., 2019: Literackie inspiracje. Rozmowa z Lidiją Dimkovska, autorką powieści „Non-Oui”. „Książki. Magazyn Literacki”, nr 4, s. 20-21.

Kultura. Możliwość. Działanie, [online]. Dostępne w Internecie: http://www.ofi cyna21.pl/index.php [dostęp: 4.07.2019].

Oto książki nominowane do Literackiej Nagrody Europy Środkowej Angelus w 2019 roku. Dostępne w Internecie: https://wroclaw.naszemiasto.pl/oto -ksiazki-nominowane-do-literackiej-nagrody-europy/ar/c13-5200361 [dostęp: 25.08.2019].

Guławska-Gawkowska M., Hejwowski K., Szczęsny A., red., 2012: Tłumacz: sługa, pośrednik, twórca? Warszawa, Instytut Lingwistyki Stosowanej Uniwersytetu Warszawskiego.

Tokarz B., 2008: Bariery kulturowe w przekładzie. W: P. Fast, P. Janikowski, A. Olszta, red.: Odmienność kulturowa w przekładzie. Katowice, Wydawnictwo Śląsk-Częstochowa, Wydawnictwo Wyższej Szkoły Lingwistycznej, s. 7-23.

Tomala L., 2019: Czy tłumacz symuluje w głowie to, co tłumaczy? Sprawdzi to filolożka. „PAP — Nauka w Polsce”. Dostępne w Internecie: http://naukawpolsce. pap.pl/aktualnosci/news\%2C77907\%2Cczy-tlumacz-symuluje-w-glowie-co -tlumaczy-sprawdzi-filolozka.html [dostęp: 12.08.2019]. 
Алаѓозовски Р., 2016: За отсутното. „Економија и бизнис”, nr 221.

Андреевски Ц., 1991: Разговори со Конески. Скопје, Култура.

Тодоровски Г., 2018: Абирмација на политичкиот есеј. W: Р. Павловски,

Александар и иунглата. Скопје, Матица македонска, s. 273-276.

Спасов Љ., 2017: Блаже Конески во 21. Век. „Стожер”, nr 125, s. 5-6.

\section{Лила Мороз-Гжелак}

\section{Македонска проза од 21 век \\ Литература на „малата нација“во преводи на полски}

РЕЗИМЕ | Во статијата се зборува за проблематиката на современата македонска проза во преводи на полски јазик, што беа излезени во 21 век. Во превод се појавија романи или раскази од десет автори, а тоа се Луан Старова, Гоце Смилевски, Лидија Димковска, Блаже Миневски, Ермис Лафазановски, Румена Бужаровска, Бранко Прља, Александар Прокопиев, Жарко Кујунџиски и Радован Павловски. Прегледот на нивната проза, исто така, укажува на имињата на полските преведувачи и уметноста на нивните стратегии за превод. Беа презентирани и издавачките куќи чија амбиција е да промовираат добра литература. Преводите на македонски дела го потврдуваат нивото на развој на оваа литература, за која се осврна Блаже Конески, признаен во Македонија како главен креатор на културата, јазикот и литературата на својата земја.

Клучни зБорови | Блаже Конески, македонската литература, преводи, литература на малата нација, преведувачи на македонската литература во Полска

\section{Lilla Moroz-Grzelak \\ 21st Century Macedonian Prose Literature of the "Small Nation" in Translations into Polish}

SUMMARY | This article presents translations of Macedonian prose that have appeared on the Polish publishing market within the 21st century. Ten authors whose novels or stories have been made available in translation are mentioned, including Luan Starova, Goce Smilevski, Lidija Dimkovska, Blazhe Minevski, Ermis Lafazanovski, Rumena Buzharovska, Branko Prlja, Aleksandar Prokopiev, Zharko Kujundzhiski, and Radovan Pavlovski. The names of Polish translators of their work are also given, accompanied by discussion of the aesthetic qualities of their work. The output of contemporary Macedonian writers appears mostly through small, private publishing houses that have the ambition to promote fine literature; the translations under discussion are evidence of the high literary quality that modern Macedonian writers have achieved. Special acknowlegement is given to Blazhe Koneski, recognized in Macedonia as a leading creator within the country's culture, language, and literature.

KEYWORDS | Blaze Koneski, Macedonian Literature, literature of a small nation, Polish translators 
LILLA MOROZ-GRZELAK | dr hab., profesor w Instytucie Slawistyki PAN; badaczka literatur i kultur południowosłowiańskich. Jej zainteresowania naukowe obejmują literaturę i kulturę Słowian południowych, a także wyrosłe $\mathrm{w}$ tej przestrzeni mity oraz ich polską perspektywę. Współautorka opracowania Bibliografia słowianoznawstwa polskiego za lata 1996-2000. Słowiańszczyzna zachodnia i południowa (Warszawa 2002), a także autorka licznych artykułów dotyczących zagadnień związanych z przemianami ideowymi w kulturach serbskiej, macedońskiej, bułgarskiej i bośniackiej. Autorka monografii Aleksander Wielki a macedońska idea narodowa. Słowiańskie losy postaci antycznej (Warszawa 2004) oraz wyróżnionego w konkursie o Nagrodę im. Jerzego Skowronka studium Bracia Słowianie. Wizje wspólnoty a rzeczywistość (Warszawa 2011; 2. wyd. - Warszawa 2013). 